\title{
Phytochemical Screening and Investigation of Antimicrobial Activity from Derivatives of Aveloz (Euphorbia tirucalli L.)
}

\author{
Aleixo $\mathrm{TB}^{1}$, Calmon $\mathrm{JR}^{1}$, Falconi $\mathrm{AP}^{1}$, Souza $\mathrm{AR}^{2}$, Duarte $\mathrm{RS}^{4}$, Fagundes $\mathrm{LL}^{1,3}$ and Machado $\mathrm{RRP}^{1,3^{*}}$ \\ ${ }^{1}$ Faculty of Medical Sciences and Health of Juiz de, Fora Suprema, Alameda Salvaterra, 200, Juiz de Fora - MG, Brazil, CEP: \\ 36033-003 \\ ${ }^{2}$ Foundation Center for Science and Higher Education Distance from the State of Rio de Janeiro - Polo Professor Darcy \\ Ribeiro, Rua 539 s/n, Jardim Paraíba, Volta Redonda - RJ, Brazil, CEP: 27215500 \\ ${ }^{3}$ Hospital and Maternity Therezinha de Jesus. Rua Dr. Dirceu de Andrade, 33 - São Mateus, Juiz de Fora - MG, 36025-140; \\ ${ }^{4}$ Laboratory of Mycobacteria, Institute of Microbiology Paulo de Góes, Health Sciences Center, Federal University of Rio de \\ Janeiro, Block I, University City, Fundão Island, Rio de Janeiro, RJ, CEP 21941-902, Brazil
}

Received: April 28, 2018; Accepted: May 23, 2018 ; Published: June 1, 2018

*Corresponding author: Machado RRP, Faculty of Medical Sciences and Health of Juiz de Fora - Suprema. Alameda Salvaterra, 200, Juiz de Fora - MG, Brazil, Email: rachel.machado@suprema.edu.br

\begin{abstract}
Aveloz (Euphorbia tirucalli L.) is a plant known for its therapeutic activities and the toxicity of latex. Antimicrobial, antitumoral, antidiarrheal, anti-inflammatory activities, among others, are examples of its medicinal properties already described in different studies. On the other hand, extrinsic and intrinsic factors associated with the plant metabolism are able to produce different metabolites among samples of the same species. Therefore, studies of antimicrobial activity and the phytochemical screening of different specimens of this plant are relevant, since it is able to aggregate knowledge about its properties widely used by the population. In the present study, the phytochemical screening was performed and the antimicrobial activity of four extracts from aerial parts was investigated. The results showed that the material presents antimicrobial and anti-inflammatory potentials, since the phytochemical screening revealed the presence of flavonoids and, through the susceptibility tests carried out on 96-wells microplates with viability stains, it was verified the occurrence of growth inhibition of Pseudomonas aeruginosa and Escherichia coli strains. The plant derivatives presenting significant antimicrobial activity were the ethyl acetate and the butanol extracts. Comparing these data to the literature we conclude that new researches using different specimens of $E$. tirucalli may provide findings with potential application in medicine.
\end{abstract}

Keywords: Euphorbia tirucalli L., aveloz, phytochemical screening, antimicrobial potential.

\section{Introduction}

Historically, medicinal plants have always been an important source of compounds for drugs production, in the form of pure active principles or as traditional preparations. Therefore, using natural resources for therapeutic purposes is considered an ancient practice and can be equated with the emergence of human civilization [1,2].
Currently, several factors support the use of medicine plants, such as the wide range of adverse effects of chronic use of industrialized drugs with chronic use, increased consumption of natural products by the population, and a tendency to use the traditional medicine based on the concept that it could be free of adverse effects. However, it is known that it does not present scientific support, but it has been passed down through the generations [3].

Self-medication, probably originated in traditional and/ or family practices trough years, leads to the indiscriminate use not only of plant drugs in home preparations, but also of industrialized drugs. This fact leads to drugs interactions, which can lead to severe reactions such as the potentiation of the drug effect or to the inactivation of the active substances. In addition, the toxic effects of many plant drugs are still unknown and represent a potential risk to the population [3].

In recent decades, the Brazilian government has been interested in linking popular knowledge about medicinal plants to the sustainable development, and the Resolution RDC No. 17, of February 24, 2000, was published, classifying phytotherapeutics as medicines [4].

Euphorbia tirucalli Lineau, popularly known as aveloz, has a high toxicity in its latex (part of the plant most commonly used). This plant belongs to the family Euphorbiaceae and originates from Africa and America. Later it was introduced in Brazil and has adapted to the hot climate regions of the country, especially in the North and Northeast, where it has propagated as an ornamental plant widely used as protection against invasors [5].

Morphologically, this plant can be described as presenting extremely cylindrical green and branched stem with small leaves 


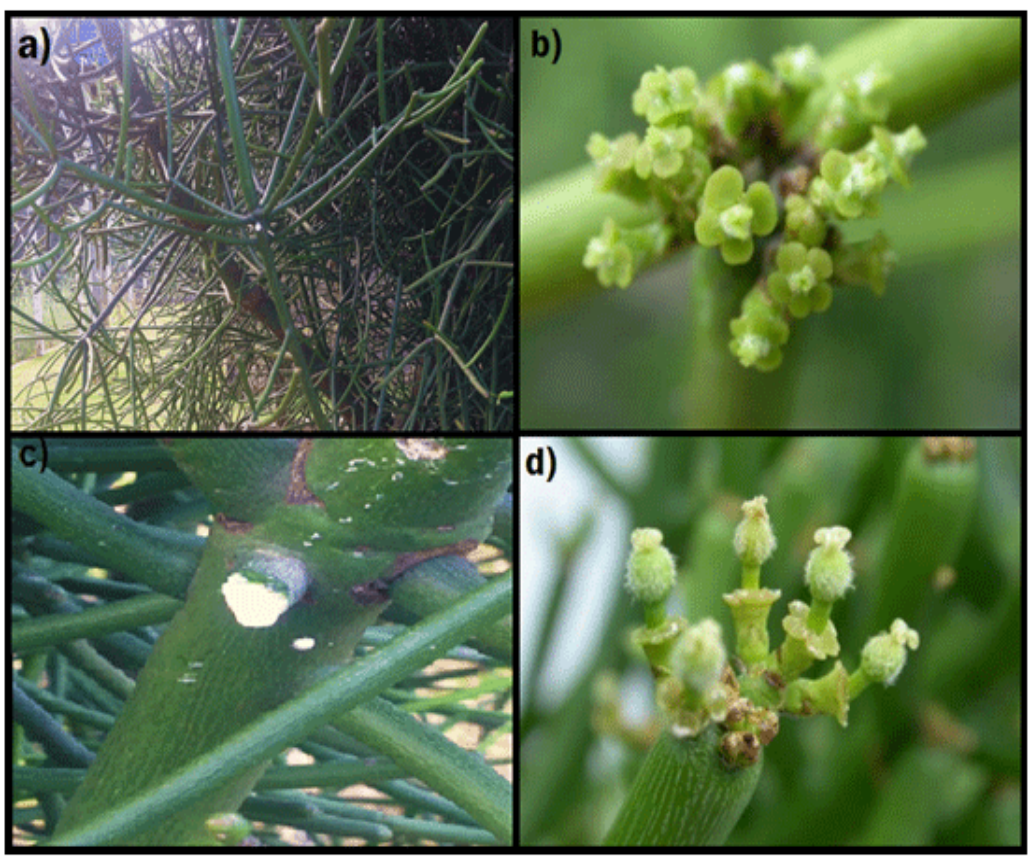

Figure 1: Images of Euphorbia tirucalli L.

a) Tree of E. tirucalli in Horta Piatã at the Faculty of Medical Sciences and Health of Juiz de Fora;

b) Presence of small terminal flowers in the plant

c) Latex from the stem recently broken;

d) Encapsulated fruit of E. tirucalli

that appear only at the beginning of its development, small female and male terminal flowers and encapsulated fruit containing three ovoid seeds (Figure 1).

The stem of E. tirucalli produces caustic and toxic latex (Figure 1C), that has been used to treat some diseases, such as helminthiasis, syphilis, and tumors. This latex is extremely dangerous for domestic use, since it is corrosive in contact with the skin, which can cause lesions, itching, edema, burns and even tissue necrosis. In contact with the eyes it causes swelling, burning, blurred vision and, if the victim does not have prompt medical attention, the lesions may progress to the cornea's destruction causing permanent blindness. When ingested, latex may cause vomiting, diarrhea, and bleeding due to the irritation of the gastric mucosa. Ingestion of high doses of latex diluted in water can cause vasoconstriction, tissue hypoxia and increase of blood clotting. Due to these characteristics, it was cataloged in the National Information Program on Toxic Plants of the Oswaldo Cruz Foundation [7-11].

Additionally, in Brazil, there are reports of the use of E. tirucalli latex by the population as an antimicrobial agent, besides being used as a treatment of intestinal constipation, asthma, coughs, otitis, arthralgias and papillomas. However, the dosage used for these different types of pathologies varies based only on the empirical knowledge [12-15].

In this sense, E. tirucalli is one of the plant species exploited by the scientific community. And, in order to contribute to increase the knowledge about the use of this plant, the present study evaluated the potential antimicrobial activity of the extracts obtained from the aerial parts of E. tirucalli and carried out a phytochemical screening to identify the classes of chemical substances present in these plant extracts.

\section{Material and Methods}

\section{Collection of the plant drug}

The aerial parts of the plant drug E. tirucalli, popularly known in Brazil as graveto-do-cão, figueira-do-diabo, dedo-do-diabo, pau-pelado, São Sebastião's tree, aveloz or avelós, were collected from the Piatã garden at the Faculty of Medical Sciences and Health of Juiz de Fora (FCMS / SUPREMA - JF) on 05/31/2017. Its geographical location is given by the following coordinates $-21.8163711 /-43.3816181$. The plant was identified by the curator Dr. Luiz Menini Neto, and the sample of material was registered in the Leopoldo Krieger Herbarium - CESJ 19803, at the Federal University of Juiz de Fora - Minas Gerais - Brazil.

\section{Preparation of plant derivatives}

The collected samples were hand-cut and cut with scissors, which sizes ranging from 2.0 to $4.0 \mathrm{~cm}$ and were later weighed with a scale in a becker. $91.7 \mathrm{~g}$ of the sample were placed in a glass container then, in the chapel of exhaustion, $917 \mathrm{~mL}$ of hexane $\left(\mathrm{C}_{6} \mathrm{H}_{14}\right)$ were added. After seven days, the supernatant was collected, duly stored and identified in an amber glass vial. In the glass container with the sample, $917 \mathrm{~mL}$ of dichloromethane 
$\left(\mathrm{CH}_{2} \mathrm{Cl}_{2}\right)$ were added and again, after seven days, that supernatant was collected, duly stored and identified in an amber glass vial. In the glass container with the sample, $917 \mathrm{~mL}$ ethyl acetate $\left(\mathrm{CH}_{3} \mathrm{COOCH}_{2} \mathrm{CH}_{3}\right)$ were added, and the same method was followed with the supernatant obtained, also repeating it with butanol $\left(\mathrm{C}_{4} \mathrm{H}_{100}\right)$. For the addition of the solvents and transposition of the supernatants, a $250 \mathrm{~mL}$ graduated beaker (3 complete dosages plus a dosage of $167 \mathrm{~mL}$ ) was used. The containers were covered with aluminum foil with the shiny part turned inwards and, the extract was covered with a clear PVC film. Finally, the extracts were concentrated by evaporation of the solvents in a rotary evaporator, resulting in: hexane extract (EHEX); dichloromethane extract (EDCM); extract in ethyl acetate (EACET) and butanol extract (EBUT).

\section{Evaluation of the antimicrobial activity of plant derivatives}

In order to execute the susceptibility tests with the plant derivatives, cultures of the following microorganisms were used: Staphylococcus aureus (ATCC 6538); Pseudomonas aeruginosa (ATCC 15442) and Escherichia coli (ATCC 25922) in liquid culture (Brain Heart Infusion - BHI). The tests were carried out in the log phase of bacterial development.

96-well microtiter plates were used to verify the antimicrobial potential of the plant derivatives, using resazurin solution as a bacterial viability developer. The solutions tested were initially solubilized in DMSO (Dimethyl Sulfoxide) and then in the liquid culture (BHI). The final concentration of DMSO in these solutions was $10 \%$. The wells of the margins of each microplate were filled with sterile water in order to reduce the evaporation of the samples, which were occupying the inner part of the microtiter plates. The water-free wells were filled with $100 \mu \mathrm{L}$ of $\mathrm{BHI}$ culture. Then $100 \mu \mathrm{L}$ of the solutions of the plant derivatives to be tested were added to the first wells of the "B" line in the microtiter plates. From these, serial dilutions were performed for the wells of the following lines (B to C, C to D ...). Then $100 \mu \mathrm{L}$ of the bacterial suspensions (105CFU / $\mathrm{mL}$ ) were added and the final concentrations of the solutions of the tested materials in the microtiter plates were: EHEX - $375 \mu \mathrm{g} / \mathrm{mL}, 187.5 \mu \mathrm{g} / \mathrm{mL}$ $93.75 \mu \mathrm{g} / \mathrm{mL}(\ldots) 2.9297 \mu \mathrm{g} / \mathrm{mL}$; EDCM - $625 \mu \mathrm{g} / \mathrm{mL}, 312.5 \mu \mathrm{g} /$ $\mathrm{mL}$, (...) $4.88 \mu \mathrm{g} / \mathrm{mL}$; EACET - $250 \mu \mathrm{g} / \mathrm{mL}, 125 \mu \mathrm{g} / \mathrm{mL}, 62.5 \mu \mathrm{g} /$ $\mathrm{mL}$ (...) $1.953 \mu \mathrm{g} / \mathrm{mL}$; EBUT - $500 \mu \mathrm{g} / \mathrm{mL}, 250 \mu \mathrm{g} / \mathrm{mL}, 125 \mu \mathrm{g} / \mathrm{mL}$ (...) $3.90625 \mu \mathrm{g} / \mathrm{mL}$. Ciprofloxacin was used as a positive control, using a two factor dilution: $100-0.196 \mu \mathrm{g} / \mathrm{mL}$. The microtiter plates were maintained for 18 hours in culture oven at $37^{\circ} \mathrm{C}$ and then $10 \mu \mathrm{L}$ of the resazurin solution were added to the wells and after 6 hours the visual reading was performed so that the change from blue to pink indicated bacterial growth. Thus, Minimum Inhibitory Concentration (MIC) was determined as the lowest concentration tested on the microplate that showed no color change. The MIC values were determined based on the means of triplicates. In addition, all procedures were repeated at least three times in a period of two weeks, each of them performed in triplicate.

\section{Phytochemical screening}

The phytochemical analysis consisted on the detection of the following chemical classes of metabolites derived from secondary metabolism [16]

Flavonoids: $20 \mathrm{~mL}$ of $70 \%$ ethanol were added to $5.0 \mathrm{~g}$ of the plant drug and heated until boiling. The hydro-alcohol extract was filtered at room temperature and distributed into 4 tubes containing $3.0 \mathrm{~mL}$ each. One of the tubes was used as negative control (tube 4) and the others (tubes 1,2 and 3) were used in the identification reactions.

For the Shinoda reaction, 1 metal magnesium fragment and $1.0 \mathrm{~mL}$ concentrated hydrochloric acid was added to tube 1; for the reaction with ferric chloride, $1.0 \mathrm{~mL}$ of the $4.5 \%$ ferric chloride solution was added to tube 2 and for reaction with sodium hydroxide, $1.0 \mathrm{~mL}$ of $5 \%$ sodium hydroxide solution was added to the tube 3 .

For the reaction with aluminum chloride a circular cut of filter paper was used and 2 drops of the hydroalcoholic extract were added in different places. $50 \mu \mathrm{l}$ of the aluminum chloride solution was added to one of them. The paper was then observed under ultraviolet light.

Alkaloids: $20.0 \mathrm{~mL}$ of $1 \% \mathrm{HCl}$ were added to $2.0 \mathrm{~g}$ of the plant drug. The solution was heated without boiling for 2 minutes and, at room temperature, it was filtered into a separatory funnel. Thereafter, $10 \%$ ammonium hydroxide was added until the mixture became alkaline, which was observed with a pH indicator paper. To this solution it was added $5.0 \mathrm{~mL}$ of chloroform, and then the aqueous and organic layers were separated and collected. The organic extract was concentrated and $2.0 \mathrm{~mL}$ of $1 \%$ $\mathrm{HCl}$ was added thereto. $50.0 \mu \mathrm{L}$ of the acid solution obtained and $50.0 \mu \mathrm{L}$ of a general alkaloid reaction were placed in 6 test tubes (Dragendorff, Mayer, Bertrand, Bouchardat, Silicotungstic Acid and Picric Acid, respectively). The solution and the reactives were mixed with glass rods and the reactions were observed.

Cardiotonics: $20.0 \mathrm{~mL}$ of $50 \%$ ethanol was added to $2.0 \mathrm{~g}$ of the plant drug. This solution was boiled and then filtered at room temperature. Then $5.0 \mathrm{~mL}$ saturated lead acetate solution was added. This solution was centrifuged and the supernatant was placed on a separatory funnel. To this solution was added $5.0 \mathrm{~mL}$ of chloroform and the aqueous and organic layers were separated and collected. The chloroform extracts obtained were distributed in 3 test tubes (tubes 1,2 and 3) and concentrated in a water bath. In tube 1, the Liebermann-Bouchard reaction was carried out. The residue was taken up with $0.5 \mathrm{~mL}$ of acetic anhydride and, by the walls of the test tube; $1.0 \mathrm{~mL}$ of concentrated sulfuric acid was carefully added, without stirring. In tube 2, the Kedde reaction was performed. To the residue were added $250 \mu \mathrm{L}$ of $1 \%$ alcoholic solution of 3,5-dinitrobenzoic acid $100 \mu \mathrm{L}$ of $1 \mathrm{~N}$ $\mathrm{KOH}$ solution. In tube 3, the Keller-Killiani reaction occurred. The residue was dissolved in about $1 \mathrm{~mL}$ of glacial acetic acid and then $100 \mu \mathrm{l}$ of $2 \%$ ferric chloride was added. Then, carefully, by the walls of the tube, $1.0 \mathrm{~mL}$ of concentrated sulfuric acid was added, without stirring. 
Saponins: $10.0 \mathrm{~mL}$ of distilled water was added to $1.0 \mathrm{~g}$ of the drug. The solution was boiled and, after cooling, the obtained extract was vortexed for 15 seconds. It was observed if there was any foam formation in it.

Tannins: $10.0 \mathrm{~g}$ of the plant drug was diluted in $100.0 \mathrm{~mL}$ of distilled water. The solution was boiled for 3 minutes, cooled and filtered. The filtrate was distributed into 5 test tubes $(1,2,3,4$, and 5) and the identification reactions were assayed. Tube 1 was used as negative control. For the reaction with gelatin, $150 \mu \mathrm{L}$ of $2 \%$ gelatin solution were added to tube 2 . For the reaction with alkaloids, $150 \mu \mathrm{L}$ of $1 \%$ quinine hydrochloride were added to tube 3. For heavy metal reactions $150 \mu \mathrm{L}$ of $4 \% \mathrm{Cu}(\mathrm{AcO})_{2}$ solution were added to tube 4 , and in tube 5 were added $150 \mu$ lof the $10 \%$ $\mathrm{Pb}(\mathrm{AcO})_{2}$, solution.

Anthraquinones: In $3.0 \mathrm{~g}$ of the drug was added $10.0 \mathrm{~mL}$ of ether. The extract formed was collected and put in a test tube. The procedure was repeated twice, collecting the extracts obtained and putting it in the same test tube. To this was added $1.0 \mathrm{~mL}$ of $10 \%$ ammonium hydroxide. The mixture was stirred for about 1.0 minute. It was observed if there was the presence of free anthraquinones.

Investigation of O-Glycosides was performed as follows: to the reserved plant drug of the first experiment, $20.0 \mathrm{~mL}$ of distilled water was added and boiled for 2 minutes. Then, $5.0 \mathrm{~mL}$ of $10 \%$ $\mathrm{HCl}$ was added and boiled for another 2 minutes. The mixture was filtered to a separatory funnel and $8.0 \mathrm{~mL}$ of hexane was added. The organic layer was collected and the aqueous acid layer was reserved for the next experiment. $3 \mathrm{~mL}$ of diluted ammonia was added to the organic layer, stirred, and then allowed to stand.

For the identification of C-glycosides, $3.0 \mathrm{~mL}$ of $5 \%$ ferric chloride were added to the acidic aqueous phase and boiled for 3 minutes. The mixture was filtered to a separatory funnel and to it was added $8.0 \mathrm{~mL}$ of hexane. Thereafter, the organic layer was collected in a test tube and the acidic aqueous layer was discarded. To the organic layer $3.0 \mathrm{~mL}$ of ammonia was added. The mixture was stirred, and then it was allowed to stand.

\section{Results and Discussion}

Antimicrobial susceptibility tests revealed the occurrence of antimicrobial activity for almost all the extracts against at least one of the bacterial species tested. The most active plant derivatives were ethyl acetate and butanolic extracts, however the $S$. aureus species' growth wasn't inhibited by any of the extracts tested. Vale et al. (2011), using aerial parts of aveloz, identified the absence of antimicrobial of activity dry extract on $S$. aureus and detected an inhibitory effect using the fresh extract [17] Growth inhibition of P. aeruginosa and E. coli was identified in the present study, as well as in studies by Upadhyay et al. (2010) [14].

In the present study, latex did not have its antimicrobial potential evaluated; however, previous studies have shown absence of bactericidal activity in this plant derivative [18-20].

The results for the tests using the reference antibiotic (ciprofloxacin) showed that the microorganisms tested were sensitive to it as shown in other studies (Table 1) [21,22].
Table 1: Antimicrobial activity of plant derivatives of aveloz on Pseudomonas aeruginosas, Escherichia coli and Staphylococcus aureus

\begin{tabular}{|c|c|c|c|}
\hline $\begin{array}{c}\text { Materials } \\
\text { Tested }\end{array}$ & $\begin{array}{c}\text { P. aeruginosa } \\
\text { CIM }(\boldsymbol{\mu g} / \mathbf{m L})\end{array}$ & $\begin{array}{c}\text { E. coli } \\
\text { CIM }(\boldsymbol{\mu g} / \mathbf{m L})\end{array}$ & $\begin{array}{c}\text { S. aureus } \\
\text { CIM }(\boldsymbol{\mu g} / \mathbf{m L})\end{array}$ \\
\hline EHEX & 187,5 & $\mathrm{n} / \mathrm{a}$ & $\mathrm{n} / \mathrm{a}$ \\
\hline EDCM & $\mathrm{n} / \mathrm{a}$ & $\mathrm{n} / \mathrm{a}$ & $\mathrm{n} / \mathrm{a}$ \\
\hline EACET & 62,5 & 250 & $\mathrm{n} / \mathrm{a}$ \\
\hline EBUT & 62,5 & 250 & $\mathrm{n} / \mathrm{a}$ \\
\hline Ciprofloxacin & 3,125 & 0,37 & 6,25 \\
\hline
\end{tabular}

Extracts: EHEX (extract in hexane); EDCM (extract in dichloromethane); EACET (extract in ethyl acetate); EBUT (butanol extract); $\mathrm{n} / \mathrm{a} \rightarrow$ no activity.

Despite the antimicrobial activity identified in the present study, the toxic potential of this plant acts as a limiting characteristic of its use as a source of antimicrobial potential. In this sense, tests performed by Silva et al. (2007) on the toxicity of aqueous extract of aveloz in pregnant rats did not identify clinical signs of toxicity [5]. On the other hand, Waczuk (2014) and Neodini (2015) found toxic activity in the aqueous and ethanolic extracts of the aerial parts of the aveloz $[23,24]$. In relation to the latter, the mechanisms of action related to toxic activities have not been completely clarified, requiring future studies.

With regard to the results obtained through phytochemical screening, it was possible to identify the presence of flavonoids. To evaluate the presence of flavonoids, four reactions were performed and all of them showed positive results. Shinoda's reaction slowly revealed the color development that ranged from rosy to reddish; by using the reaction with ferric chloride it was observed the appearance of a color that varied between

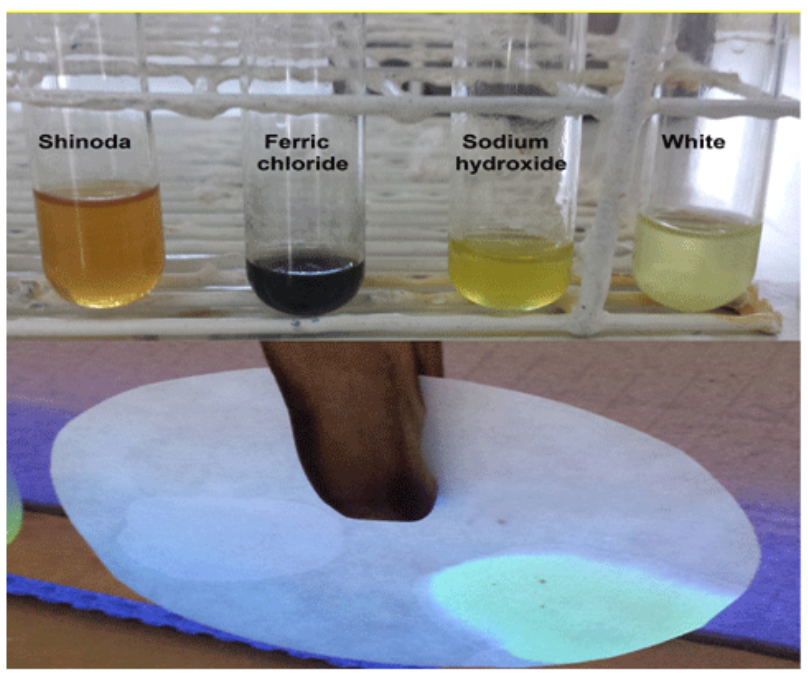

Figure 2: Results of the reactions for identification of flavonoids: a) Tubes showing Shinoda reaction, reaction with ferric chloride, reaction with sodium hydroxide and white;

b) Filter paper revealing the presence of flavonoids (note fluorescence) by the reaction with aluminum chloride. 
shades of dark green and brown; for the reaction with sodium hydroxide it was observed the appearance of yellow color that varied in intensity when shaking the tube; and the reaction with aluminum chloride it was noticed the appearance of fluorescence in the region of the filter paper in which the reactive was applied (Figure 2).

The presence of flavonoids in phytochemical screening is justified by the fact that flavonoids are known as one of the broadest groups of secondary metabolites of plants, being important natural pigments widely found in different parts of plants. The great diversity in the structure of flavonoids occurs due to some subtle modifications in its chemical composition, in its basic structure, and it may be through hydroxylation, methylation, acylation, glycosylation, hydrogenation, malonylations and sulfation. [25,26].

Several activities of the flavonoids in the organism have been observed, such as: vasodilatation, antioxidative potential, anti-inflammatory, antiallergic, antitumor, anti-hepatotoxic, antiulcerogenic and antiplatelet activities, as well as antimicrobial and antiviral actions [25].

Thus, considering that phytochemical screening revealed only flavonoids, it is possible to infer that the antimicrobial activity verified from the tested plant derivatives may be related to this class of secondary metabolites.

The reactions of identification of the alkaloids were negative, because there was no formation of precipitates or turbidity in any of the tubes that received the reactives (Figure 3).

Cardiotonic compounds were tested by three reactions. Two of them presented a positive result and one presented a negative result. The first positive reaction was that of LiebermannBouchard, because the appearance of a reddish ring in the contact zone of the two layers was observed; the second positive reaction was that of Keller-Killiani because of the appearance of red-brownish coloration in the zone of contact of the liquids and green coloration in the acetic layer. The only negative reaction was Kedde's reaction, as the intense red-violet color expected to appear was not evident (Figure 4). Thus, we consider the result

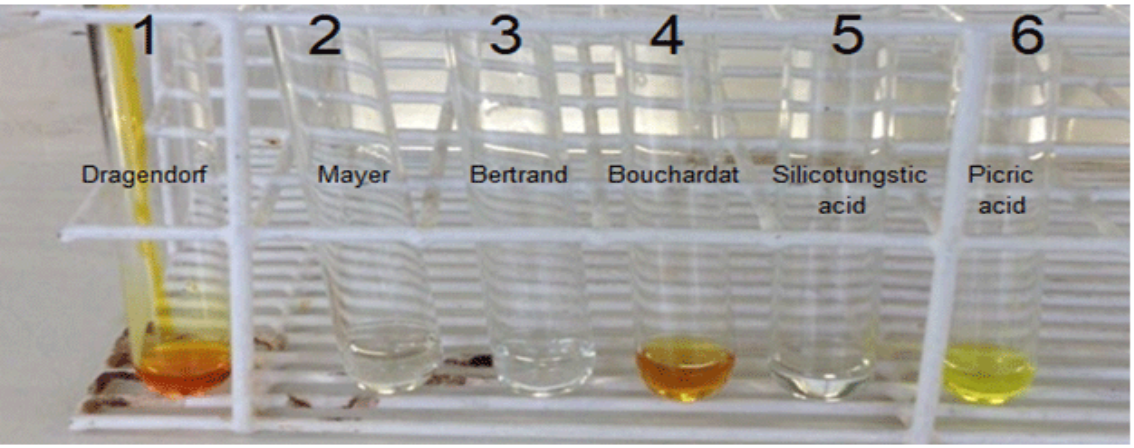

Figure 3: Results of reactions to alkaloid identification: Tubes showing negative reaction results with Dragendorff (tube 1), Mayer (tube 2), Bertrand (tube 3), Bouchardat (tube 4), Silicotungstic Acid (tube 5) and Picric Acid (tube 6)

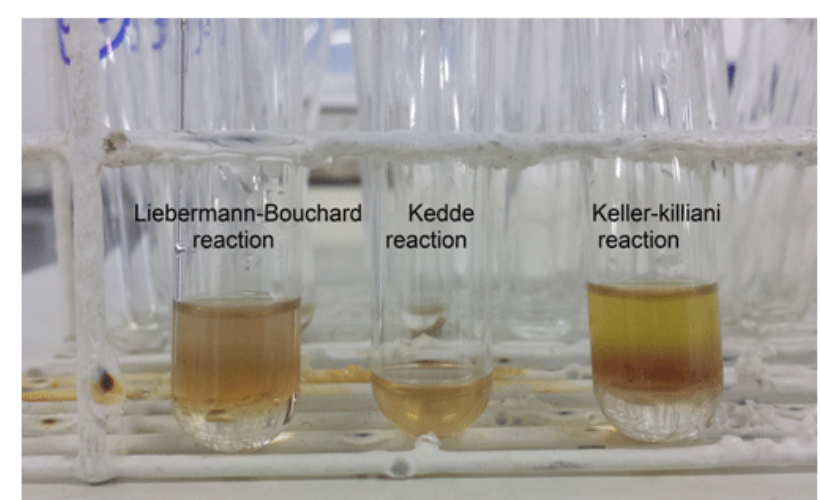

Figure 4: Results of reactions for identification of cardiotonics: Tubes showing, respectively, the reactions of Liebermann-Bouchard; Kedde and Keller-Killiani

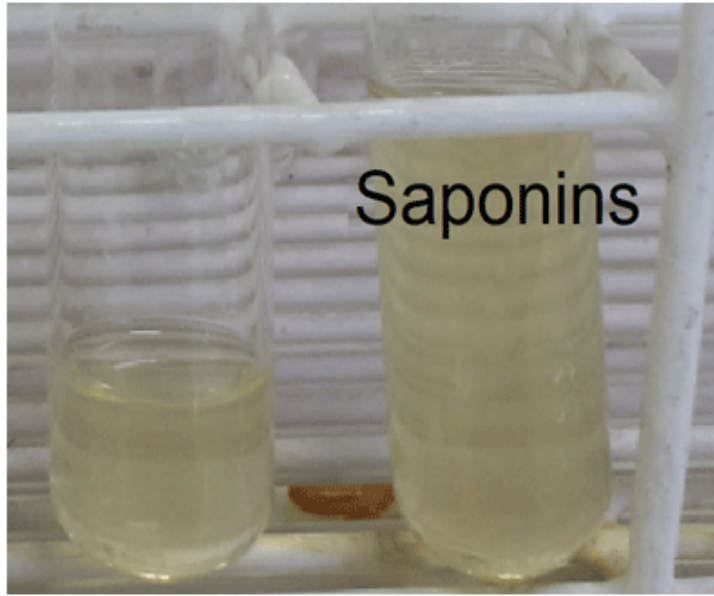

Figure 5: Results of the reactions for identification of saponins: tube with higher volume showing absence of foam in the reaction to identify saponins 
negative for cardiotonics.

In the evaluation of saponins, the reaction was negative, as there was no persistent foam formation (positivity is confirmed when the foam persists for more than 15 seconds) (Figure 5).

In relation to the tannins, the result was also negative, because no precipitation was observed in any of the three reactions proceeded (Figure 6).

Finally, to verify if the plant derivative had anthraquinones, three tests were performed. No free antraquinones were evident (Figure 7), as there was no pink or red coloration in the lower phase of the test tube during the tests. Likewise, O-Glycosides and C-Glycosides were not identified, since no red color appeared in the ammoniacal layer in order to indicate the presence of anthraquinone glycosides with C-O bond or C-C bond, respectively.



Figure 6: Results of reactions to identify tannins: Tubes showing reactions with gelatin, alkaloids, heavy metals (reaction tube using $\mathrm{Cu}(\mathrm{AcO})_{2}$ at $4 \%$ ) and white



Figure 7: Results of the free antraquinone identification reaction: tube showing negative result

Table 2 compiles literature information obtained from a survey in the Scielo databases, using the words: Euphorbia tirucalli L., aveloz, phytochemical screening and antimicrobial potential. We selected studies that presented a similar approach to the present study, regarding the phytochemical screening performed.

The comparison between the results showed that the absence of anthraquinones and cardiotonics (in relation to the studies that carried out this investigation) were the common points. In addition, it is important to point out that the material analyzed

Table 2: Comparison between phytochemical screenings of Euphorbia tirucalli L. in different studies

\begin{tabular}{|c|c|c|c|c|c|c|}
\hline Studies analyzed & & & & & & \\
\hline $\begin{array}{l}\text { Phytochemical } \\
\text { screening }\end{array}$ & (Machado et al., 2007) & $\begin{array}{l}\text { (Upadhyay et al., } \\
\text { 2010) }\end{array}$ & $\begin{array}{l}\text { (Vale et al., } \\
\text { 2011) }\end{array}$ & $\begin{array}{l}\text { (Maya et al., } \\
\text { 2012) }\end{array}$ & $\begin{array}{l}\text { (Orlanda et } \\
\text { al., 2015) }\end{array}$ & $\begin{array}{l}\text { (Present } \\
\text { Study) }\end{array}$ \\
\hline Flavonoids & + & - & + & - & + & + \\
\hline Alkaloids & + & + & + & + & + & - \\
\hline Cardiotonics & - & - & NT & NT & NT & - \\
\hline Saponins & - & - & + & + & + & - \\
\hline Tannins & + & + & - & + & + & - \\
\hline Anthraquinones & - & NT & - & - & - & - \\
\hline
\end{tabular}

in the present study was the only one that did not reveal the presence of alkaloids. This result allows us to consider the studied specimen as a potential source of new antimicrobial agents, since the alkaloids represent a group with known toxic components.

Thus, the results obtained in the present study reinforce the need to carry out continuous phytochemical and antimicrobial evaluations with different specimens of $E$. tirucalli for better characterization of antimicrobial properties.

\section{Acknowledgement}

We thank Mr. Marlei da Silva Gomes for the technical support offered at the Laboratory of Mycobacteria of the Institute of
Microbiology Paulo de Góes, Health Sciences Center, Federal University of Rio de Janeiro. We are also grateful to the Faculty of Medical Sciences and Health of Juiz de Fora - Suprema for funding the project and grant awarded.

\section{References}

1. Farnsworth NR, Akerele O, Bingel AS, Soejarto DD, Guo Z. Medicinal plants in therapy. Bull World Health Organ. 1985;63(6):965-981.

2. Ministério Da Saúde. Plantas medicinais e fitoterapia na atenção básica, 2012. Available in: http://189.28.128.100/dab/docs/ publicacoes/geral/miolo_CAP_31.pdf

3. CFF - CONSELHO FEDERAL DE FARMÁCIA DO ESTADO DE SÃO PAULO. Plantas Medicinais e Fitoterápicos, 2016. Available in: 
http://portal.crfsp.org.br/publicacoes-2/cartilhas-por-area. html?download=202: cartilha-plantas-medicinais-e-phitoterapicos

4. Anvisa - Agência Nacional De Vigilância Sanitária. Resolução RDC no 17 de 24 de fevereiro de 2000, 2008. Available at: http://www.cff org.br/userfiles/file/resolucao_sanitaria/17.pdf

5. Silva AC, de Faria DE, Borges NB, de Souza IA, Peters VM, Guerra Mde O. Toxicological screening of Euphorbia tirucalli L.: developmental toxicity studies in rats. Journal of Ethnopharmacology. 2007;110(1):154-159. doi: 10.1016/j.jep.2006.09.012

6. Costa LS. Estudo do uso do aveloz (Euphorbia tirucalli) no tratamento de doenças humanas: uma revisão. 2011. 18p. Course Conclusion Work - Concentration Area in Biology - Center for Biological and Health Sciences, Universidade Estadual da Paraíba, Campina Grande.

7. Barg Dg. Plantas tóxicas. Scientific Methodology in the Phytotherapy course - Brazilian Institute of Homeopathic Studies, Faculdade De Ciências Da Saúde De São Paulo. São Paulo-SP. 2004.

8. Caseiro BM, Ferreira EP, Grillo JGB, Araujo JHB. Estudo do potencial de cura das formas de câncer utilizando Aveloz (Euphorbia tirucalli L.). Interdisciplinary Scientific and Technological Initiation (MICTI), Colégio Agrícola de Comburiu - UFSC, Santa Catarina. 2006.

9. SINITOX - Sistema Nacional de Informações Toxico Farmacológicas. Registros de Intoxicações, 2012. Available in: https://sinitox.icict. fiocruz.br/dados-nacionais.

10. EMBRAPA - EMPRESA BRASILEIRA DE PESQUISA AGROPECUÁRIA Algumas espécies de plantas reunidas por famílias e suas propriedades, 2010. Available in: http://studylibpt.com/ doc/743174/algumas-esp\%C3\%A9cies-de-plantas-reunidas-porfam $\%$ C3\%ADlias-e-suas.

11.Santos OJ, Sauaia Filho EN, Nascimento FRF, Silva Júnior FC, Fialho EMS, Santos RHP, et al. Avaliação do uso do extrato bruto de Euphorbia tirucalli na inibição do tumor ascítico de ehrlich. Rev Col Bras Cir. 2016; 43(1):18-21.

12.Correia M P. Dicionário de Plantas úteis do Brasil e das exóticas cultivadas. Rio de Janeiro: Ministério da Agricultura e Instituto Brasileiro de Desenvolvimento Florestal. 1926.

13. Betancur-Galvis LA, Morales GE, Forero JE, Roldan J. Cytotoxic and Antiviral Activities of Colombian Medicinal Plant Extracts of the Euphorbia genus. Memórias do Instituto Oswaldo Cruz. Rio de Janeiro. 2002;97(4):541-546.

14. Upadhyay B, Singh PK, Kumar A. Ethnomedicinal, phytochemical and antimicrobial studies of Euphorbia tirucalli L. J Phytol. 2010;2(4):65-77.

15.Caxito ML, Victoria CP, Costa HB, Romão W, Kuster RM, Gattass CR. Antiproliferative activity of extracts of Euphorbia tirucalli $L$ (Euphorbiaceae) from three regions of Brazil. Tropical Journal of Pharmaceutical Research. 2017;16(5):1013-1020.

16. Miranda GS, Santana GS, Machado BB, Coelho FP, Carvalho CA Atividade antibacteriana in vitro de quatro espécies vegetais em diferentes graduações alcoólicas. Rev Bras Pl Med. 2013;15(1):104111.
17. Vale VV, Orlanda JFF. Atividade antimicrobiana do extrato bruto etanólico das partes aéreas de Euphorbia tirucalli Linneau (Euphorbiaceae). Scientia plena. 2011;7(4):1-6.

18. Rocha FAG, Dantas LIS. Atividade antimicrobiana in vitro do látex do aveloz (Euphorbia tirucalli L.), pinhão bravo (Jatropha mollissima L.) e pinhão roxo (Jatropha gossypiifolia L.) sobre microrganismos patogênicos. Holos. 2009;4:3-11.

19. Maya TPT, Castro IPM, Carneiro KM. Identificação de ativos fitoquímicos e atividade antibacteriana do latex da Euphorbia tirucalli (avelóz) coletado no município de Palmas-TO. In: Jornada Acadêmica de Biomedicina e Farmácia, CEULP/ULBRA. 2012;171174.

20.Arruda MFC, Rosa RT, Rosa EAR, Campelo PMS. Atividade antimicrobiana e toxicidade do látex de Euphorbia tirucalli L. (aveloz). Revista Cubana de Plantas Medicinales. 2015;20(4):492497.

21. Fatholahzadeh B, Emaneini M, Gilbert G, Ud E, Aligholi A, Modarressi MH, et al. Microbial Drug Resistance. Liebert Pub. 2008;14(3):217220.

22. Rezai MS, Salehifar E, Rafiei A, Langaee T, Rafati M, Shafahi K, Eslami G. Characterization of Multidrug Resistant Extended-Spectrum Beta-Lactamase-Producing Escherichia coli among Uropathogens of Pediatrics in North of Iran. BioMed Research International.2015;1-7. doi: $10.1155 / 2015 / 309478$

23. Waczuk EP. Avaliação toxicológica do extrato aquoso dos ramos de E. tirucalli L. in vitro. Dissertation (Master in Biochemistry). Department of Chemistry, Universidade Federal de Santa Maria, Santa Maria, 2014.

24.Neodini DNR, Gaspi FOG. Análise dos efeitos tóxicos da avelós (Euphorbia tirucalli L.). Revista Científica da FHO|Uniararas. 2015;3(2):1-7.

25.Lopes RM, Oliveira TD, Nagem TJ, Pinto ADS. Flavonoides. Biotecnologia Ciência \& Desenvolvimento. 2010;3(14):18-22.

26. Silva LR, Martins LV, Calou IBF, Deus MSM, Ferreira PMP, Peron AP. Flavonoides: constituição química, ações medicinais e potencial tóxico. Acta Toxicol Argent. 2015;23(1):36-43.

27. Machado MM. Perfil fitoquímico e avaliação dos principais efeitos biológicos e imunológicos in vitro da Euphorbia tirucalli L. 2007. 105p. Dissertation (Master's Degree - Pharmacy Concentration Area) - Health Sciences Center, Universidade Federal de Santa Maria, Santa Maria.

28.Orlanda JFF, Vale VV. Phytochemical analysis and photoprotective activity of theethanolic extract of Euphorbia tirucalli Linneau (Euphorbiaceae). Rev bras plants med. 2015;17(4):730-736. 